\title{
The Analysis of Academic Information System Design of IPDC Dili - Timor Leste by using EAP Approach
}

\author{
Rita Pires Soares \\ Faculty of Information Technology \\ Satya Wacana Christian University \\ Diponegoro Street, 52-60 Salatiga \\ 50711, Indonesia
}

\author{
Eko Sediyono \\ Faculty of Information Technology \\ Satya Wacana Christian University \\ Diponegoro Street, 52-60 Salatiga \\ 50711 , Indonesia
}

\author{
M. A. Ineke Pakereng \\ Faculty of Information Technology \\ Satya Wacana Christian University \\ Diponegoro Street, 52-60 Salatiga \\ 50711 , Indonesia
}

\begin{abstract}
Development of better information services in an educational institution is necessary for global competition. Information technology can be used to solve the competition problem. One of the roles of technology that can be felt is easy of store, organize and carry out a variety of data collection. Academic information system specifically designed to meet the needs of university in the field of administrative and academic.

This paper discusses information technology that can be applied in universities, especially in Instituto Professional de Canossa (IPDC). Analysis of the design of academic information system at the Instituto Professional de Canossa (IPDC) is done by using the approach of Enterprise Architecture Planning (EAP). The results obtained are the blueprints of architectural planning required in IPDC. This is Includes model data architecture, application architecture and technology architecture. One of the priorities that really need to be implemented is the academic Information System.

The benefits of this analysis is to produce the design of academic information system that can be used as a basis or foundation for the development of academic information system at IPDC so can not be separated from the universities purpose and does not eliminate the integration between business units in the IPDC . Implementation of application design can be used as a center of academic information services in IPDC.
\end{abstract}

\section{Keywords}

Enterprise Architecture Planning (EAP), Academic Information System, Institute Professional de Canossa (IPDC)

\section{INTRODUCTION}

The rapid development of technology and communication, enabling the development of better information services in an educational institution. One of the roles of technology that can be felt is easy to store, organize and carry out a variety of data collection. Academic information system specifically designed to meet the needs of college who want a computerized educational services to improve the performance, quality of service and quality competitiveness of human resources are generated.

Instituto Professional de Canossa (IPDC) Comoro Dili, Timor-Leste is a private university that dedicated to providing professional training to qualified students in the field of Computers and Office Management that has the goal of becoming a competitive technology development center, dynamic, and innovative education. Therefore, good management information is needed in IPDC so that information needs of each stakeholder can be fulfilled quickly and accurately. While the system that currently existing in IPDC in the manage academic data such as processing new student registration, re-registration of new students, class division, guardianship of students with faculty trustee, scheduling lectures, faculty performance, student attendance, coursework and grades are not using technology update that generated the data or information can not be fulfilled in a rapid, precise and accurate and is often the limiting factor to learning systems, as well as access to information about activities such as administrative support and staffing and learning activities are very less .

The lack of adoption and utilization of information systems in the operations of an impact on academic activities. Therefore the strategic planning of information systems is the first step that needs to be done to translate the vision and mission to the needs of Information Systems and Information Technology, as well as the development and implementation of information systems/information technology on an ongoing basis.

Enterprise Architecture Planning (EAP) is a method that used to build and design the architecture of information in IPDC. EAP is a methodology for enterprise architecture planning that focuses on data architecture, application architecture and technology architecture, which is oriented to the needs of the business and how the implementation of an architecture that can support the achievement of organizational goals in the IPDC [1].

This paper examines how to use EAP in analyzing the design of academic information system at the IPDC to improve college governance and aligning business strategy with the application of information technology in a college. Conceptually EA is a strategic information asset base that determines the mission, the information and technology needed to carry out the mission, and the transition process to implement the technology in response to changing needs of the organization in managing administrative and academic education at the IPDC and can improve the image of the Instituto Professionals de Canossa as a college that cares, transparent and a step forward in technology.

The scope of the discussion is limited to core areas of the college including the college operations without discussing the methods used in the accounting and finance. Information systems are built from the analysis of the EAP will be used to help manage academic information system at the IPDC. Academic information system created is web-based and does not

\section{LITERATURE REVIEW}

\subsection{Previous Research}

In the journal, entitled Exploiting Enterprise Architecture Planning for Information Systems Strategic Planning methodology is explained on harnessing the Enterprise Architecture Planning (EAP) to produce data architecture, application architecture, technology architecture and implementation plan for the enterprise direction for expansion in the future [2]. 
Researches about Enterprise Architecture Planning usage and utilization had been done in product field [2], that discuss about Enterprise Architecture Planning methodology in achieving strategic goals of an enterprise. Strategic planning begin with information requirements identification and technology utilization to increase enterprise performance. Those planning use EAP methodology to produce data architecture, application and technology for enterprise.

Research entitled "Enterprise Architecture Planning Information System at Private Colleges with the Zachman Framework". The purpose of research is to generate an implementation roadmap information system structured to bring up Enterprise Architecture using the Zachman Framework Planning. [1].

This research will be discussed about the Analysis of academic information system Design in college Instituto Professional de Canossa (IPDC) Dili East Timor by using Enterprise Architecture Planning (EAP) approach, to be able to produce a blueprint of recommendations Enterprise planning and the implementation of information systems is a priority academic college at this time.

\subsection{Enterprise Architecture}

Enterprise Architecture (EA) is a statement how an organization starts and produce good rules on IT implementations and business process in the organization to increase competitions [3]. EA continuously influencing organization management also technological area in the organization to develop Information System [4] blueprint in many fields, theoretical and practical.

There are methods and framework that can be used, such as Zachman Framework, EAP, EAS, BEAM, TOGAF ADM, GEAF and others that often used in university as references in processing complex system [5]. In this research we will adopt EAP to implement EA in IPDC.

EAP methodology consist of main components, that is, Initialization Planning, Business Model, Existing System and Technology, Data Architecture, Application Architecture Technology Architecture and Implementation Roadmap. These seven components can be grouped into 4 layers s shown on Figure 1.

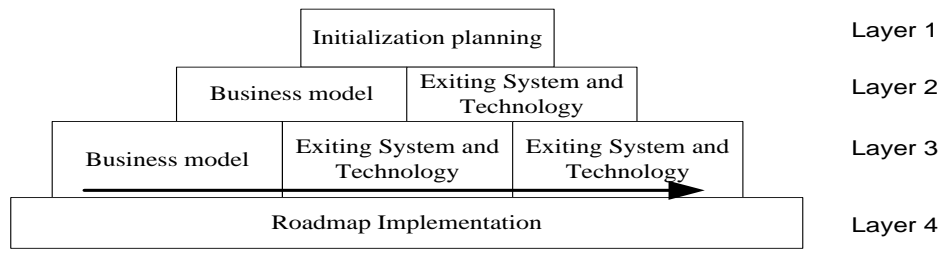

Fig. 1. EAP Components [2]

\subsection{Academic Information Systems}

Academic Information System is a resource in form of information's that has connection to academic matters in the college. Academic Information System beside as information resource in the college can also be used as communication media between lecturers and students, students and students, lecturers and officials and whoever in the university environment. Due to internet technology used not only in the campus internal but also outside campus as long as there are computers connected to the internet. Academic Information System is a web-based information system that has goal to form Knowledge Based System that can be accessed using via internet, such as student's personal data such as [6]:

1) Student Study Plan in accordance to the programmed subject in one semester
2) Student Study Result to know resulting goal in the following lectures and study evaluation results and also its GPA.

3) Lectures scheduling that contain lectures schedule, student's activity, monitoring lecturer's schedule, and attendance in lecture.

This system information will support university performance in the field of student service up to worker service. But after the fast development of information technology, an university has to always update its information system in order to increase its performance to a better point.

\subsection{The Difference between EAP and Traditional Information System}

EAP has 4 differences with traditional information system design that can be described in table 1 below;

Table 1. Differences between EAP and Traditional Information System [1]

\begin{tabular}{|c|c|c|}
\hline Differences & Traditional Information System & EAP \\
\hline Functional Business Model & $\begin{array}{l}\text { Planning begin with a whole definition about } \\
\text { business but a group of analyst asked "What kind } \\
\text { of system needed?" }\end{array}$ & $\begin{array}{l}\text { Planning by analyze "what could } \\
\text { be the critical success factor?" } \\
\text { ("What kind of information } \\
\text { needed?") }\end{array}$ \\
\hline Application and Data Definition & $\begin{array}{l}\text { Defining applications needed then defining what } \\
\text { data that has to be processed }\end{array}$ & Defining data before application \\
\hline $\begin{array}{ll}\text { Implementation } & \text { Roadmap } \\
\text { Boundaries } & \\
\end{array}$ & $\begin{array}{l}\text { Information system that will be implemented } \\
\text { become priority by company executive }\end{array}$ & $\begin{array}{l}\text { Using data connections to define } \\
\text { the implementation boundaries }\end{array}$ \\
\hline $\begin{array}{l}\text { Consideration of Operational } \\
\text { Costs }\end{array}$ & $\begin{array}{l}\text { Focusing exclusively on short term problem. } \\
\text { Usually, this approach only emphasize on business } \\
\text { area that will give profit on short term. }\end{array}$ & $\begin{array}{l}\text { EAP considering long term } \\
\text { business goal. Because of that, } \\
\text { EAP will show flexible planning to } \\
\text { achieve the goal using reasonable } \\
\text { cost. }\end{array}$ \\
\hline
\end{tabular}




\section{RESEARH MEDTHOD}

\subsection{Research Methodology}

In this research we will use inductive research method, that is, an approach to build a theory based on observation result. This approach is a procedure that rooted on special case as a result of empirical observation and ended with a conclusion or new general knowledge. In this matter, inductive approach is a reverse of deductive approach. To got to the field and research, one does not need to have sophisticated concept but only need to observe the field and from this observation, ones can conclude a generalization of some symptoms.In this context, theory is not a necessary requirement but accuracy to identify a symptom and understanding it will be a great key to describe a symptom and make generalization of it.

The research method can be done by flow interview, that is, ones does not need to use a questionnaire but use interview guide and usually using open questions which can be expanded as needed.

This research steps is called 'bottom-up' approach [7]. Inductive approach can be pictured below.

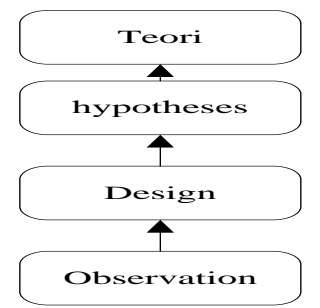

Fig. 2. Inductive Research Steps

\subsection{Systems Thinking Framework}

The research framework will include steps in EAP which ended with conclusion and transition in accordance to its implementation (see Figure 3).

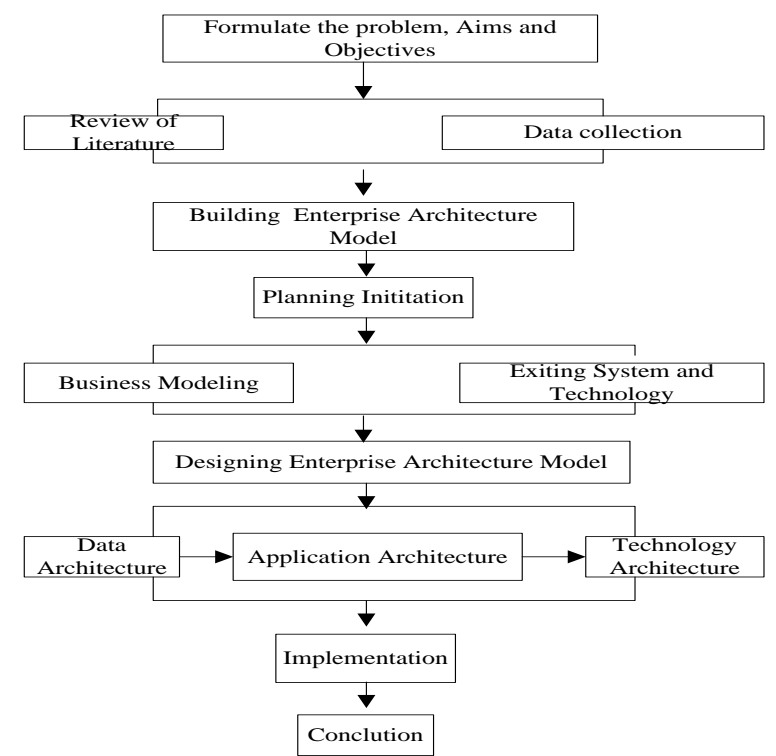

Fig. 3. System Thinking Framework

\section{RESULTS AND DISCUSSION}

In this part, we wil discus about how to build a EA model using EAP as explained in the following chapter.

\subsection{Initialization Planning}

In this step, defining about research implementation such as the EAP scope and goal, vision definition, and computer resource usage.

\section{EAP Scope and Objectives}

Instituto Professional de Canossa (IPDC) is one of private university built by Canossian sister to prepare professional young generation that ready to work and answer current era needs. Until now, IPDC serve students that have interest in office management science and computer technique via three (3) departments:

1. Bachelor degree of Office Management

2. Bachelor degree of Technical Computers and Informatics

3. Licensure of Informatics Engineering

The goal of information system and information technology of EAP that will be planned is an information system that connected with education enforcement specifically in academic field and general administration that include university operational activities without discussing methods used in accounting and monetary parts. Information system that will be built from EAP analysis result will be used to help manage the academic information system of IPDC. The Academic Information System will be web-based and we will not discuss the security aspect of the application.

\subsection{Business Modeling}

In this step we will define about organizational structure and identification and business function definition. Business model in IPDC specifically that connected to academic field and general administration can be defined as below.( see Figure 4).

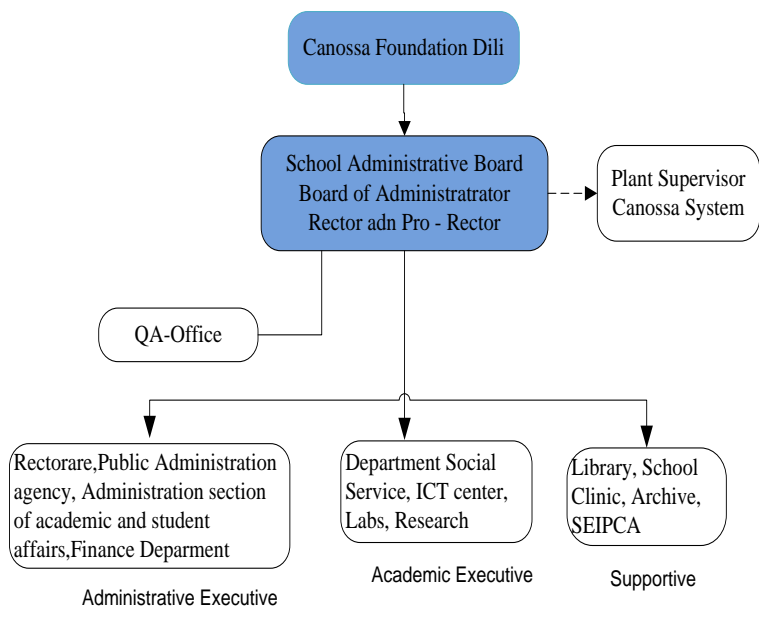

Fig. 4. General Framework of IPDC Organizational Structure, as of 2012. [8] 


\subsubsection{Identification Of Enterprise Problem}

Based on observation and review, we can find few problems connected to business process and support for information system and information technology that can be viewed on table 2:

Table 2. Enterprise Problems

\begin{tabular}{|l|l|}
\hline Problem & Description \\
\hline Business Process & Not documented well also the division of tasks is not quite clear \\
\hline IT Support & Limited human resource for IT support. \\
\hline $\begin{array}{l}\text { Information System and Information } \\
\text { Technology Usage }\end{array}$ & $\begin{array}{l}\text { Not optimally utilized in the aspect of academic service. There is } \\
\text { business function that has not got any support system that based on } \\
\text { information technology utilization. }\end{array}$ \\
\hline Supporting Infrastructure & $\begin{array}{l}\text { Supporting infrastructure for IT and information system is limited, } \\
\text { especially about bandwidth and power supply. }\end{array}$ \\
\hline Information System Application & $\begin{array}{l}\text { There are weakness on the information system application so it doesn't } \\
\text { maximally support business function such as limited access on high } \\
\text { peak transaction. }\end{array}$ \\
\hline $\begin{array}{l}\text { Documentation/Module about } \\
\text { Information System Development } \\
\text { Planning }\end{array}$ & $\begin{array}{l}\text { The documentation/modules has not given any clear direction about } \\
\text { future development of information system to support business process. }\end{array}$ \\
\hline Human Resource(IT) & $\begin{array}{l}\text { Limited competent human resource on IT field especially that has } \\
\text { ability to analyze, design and develop an academic information system. }\end{array}$ \\
\hline
\end{tabular}

\subsubsection{Business Function Of IPDC}

Based on observation on IPDC, there are two main functions that happened in IPDC, i.e., [8]

1. Administrative and academic executive that including field on new student registration, academic operational (learning process) and academic graduation.

2. Supportive role that include monetary and accounting, human resource management, and department area.
In this research, we bound the discussion on administrative and academic executive where in the implementation of information system more emphasized on academic/learning process.

\subsection{Existing System and Technology}

On its first two years since its built (2003), IPDC did not use any information system and technology to support its academic activities. In year 2005, IPDC begin to use academic information system as described in table 3 below;

Table 3. Data Collection from Information Resource Catalog IRC IPDC (2005 -2013)

\begin{tabular}{|l|l|}
\hline Header Catalogue & Description \\
\hline Full Name & Academic Information System \\
\hline Category & $\begin{array}{l}\text { To record students personal data, grading, study result printing, grade } \\
\text { transcript, student card and student data reporting }\end{array}$ \\
\hline Users' Unit & Academic Bureau, Registrar Officer \\
\hline State & Active but not maintained and updated, a lot of redundant data \\
\hline Usage & Work hour \\
\hline Implementation & 2006 \\
\hline Developer & Head of Administration Affair (internal lecturer) \\
\hline Software & Microsoft Access \\
\hline Hardware & Self-built PC (IBM) Pentium 4 \\
\hline Network & LAN \\
\hline Long term issues & $\begin{array}{l}\text { The hardware and software need to be updated/upgraded to build the system, } \\
\text { use online network so it can be accessed via web and can be integrated with } \\
\text { new student registration process, monetary data and other information system } \\
\text { that easily accessible. }\end{array}$ \\
\hline
\end{tabular}

\subsection{Designing Enterprise Architecture model}

Based on initialization planning result, problems identification and current IPDC conditions, in the following part we will discuss about data architecture model, application and technology that will be proposed to develop future information system and technology in IPDC;

\subsubsection{Data Architecture Model}

Data architecture goal is to define which data that will be used to improve and develop application architecture. Based EAP steps, data architecture define 2 (two) things, i.e.:

\subsubsection{Data Entity Candidate}

Candidate Entity data is entity that will be part of architecture planning on IPDC so the choosing procedure is based on condition of main business function. Thus, the entity that will be defined is business entity, and based on it, we will define data entity. Based on the conditions, the main business entity lists that will be defined can be seen on Figure 5 . 


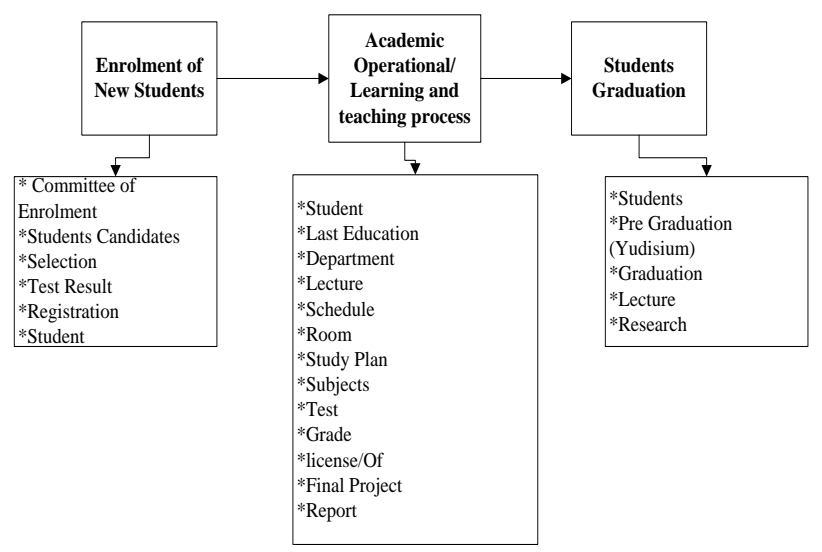

Based on Figure 5, we know that there are three main business functions in IPDC, i.e. new student registration, academic operational/learning process and student graduation process. From these there, we can further break-down into 26 data entity candidate and the one that will be priority in the design of data architecture is academic operational/learning process.

\subsubsection{Entity Relationship Diagram (ERD)}

Entity Relationship Diagram (ERD) is a diagram which describe connections between data entity that will be built, in this case, our ERD design is for academic operational functionality that will later be built into academic information system of IPDC.(see Figure 6)

Fig. 5. Data Entity Candidate

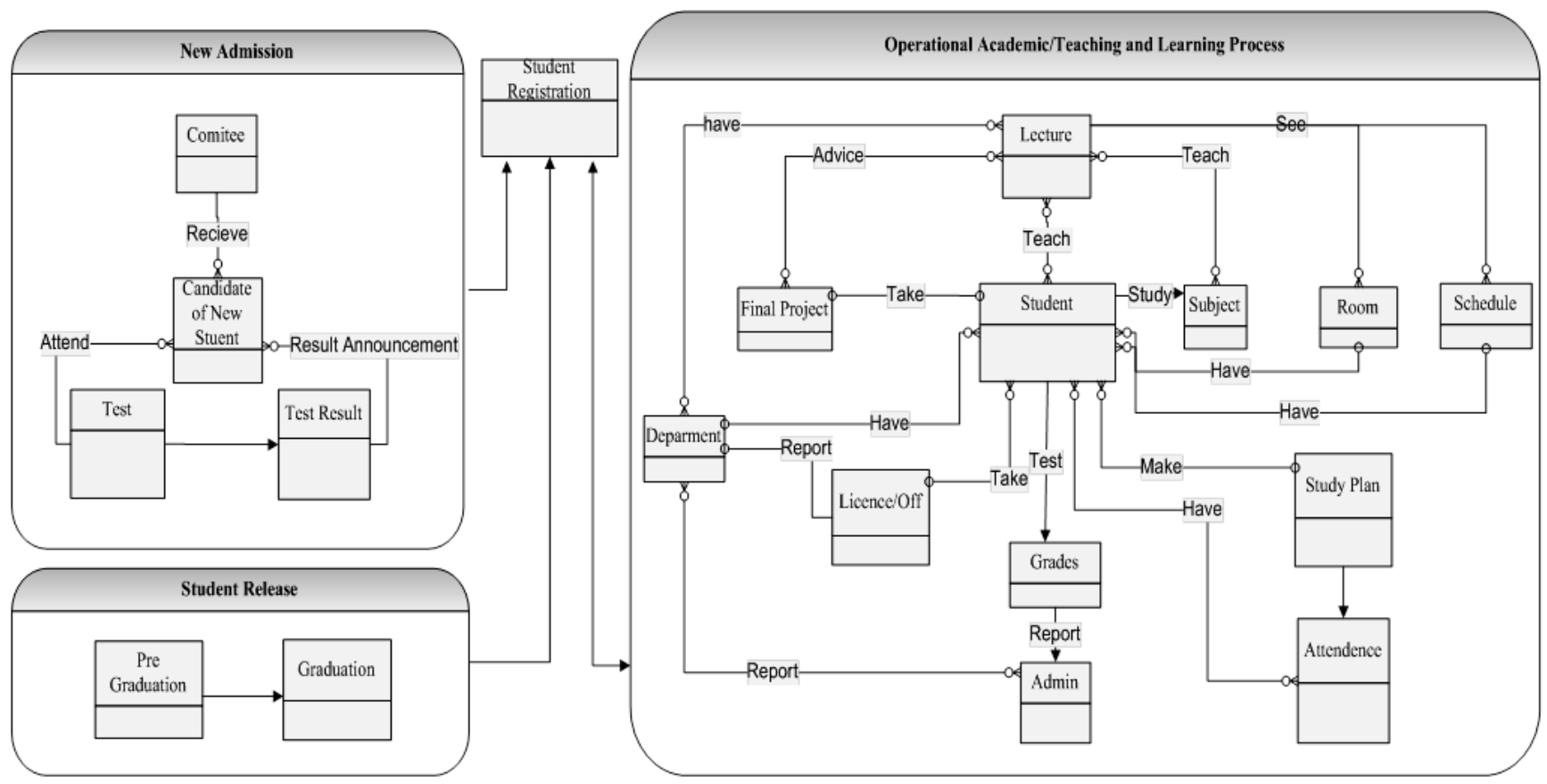

Fig. 6. Entities Relation Diagram (ERD)

\subsubsection{Application Architecture Model}

Application architecture is a definition of application that will be built that connected to previous data usage described on previous chapter. In this modeling phase, to explore system application requirements, we use management perspective and portfolio application also to develop new application based on its business process outside the existing system. [9]

Existing application need to be evaluated whether it should be improved, retained or discarded on the next year. The proposed application architecture have to be formulate target application's requirements that can be a educational portal, executive information system and non-regular lectures administration system where the application have to support organization's performance sinergically from the view of operational management (see Figure 7).

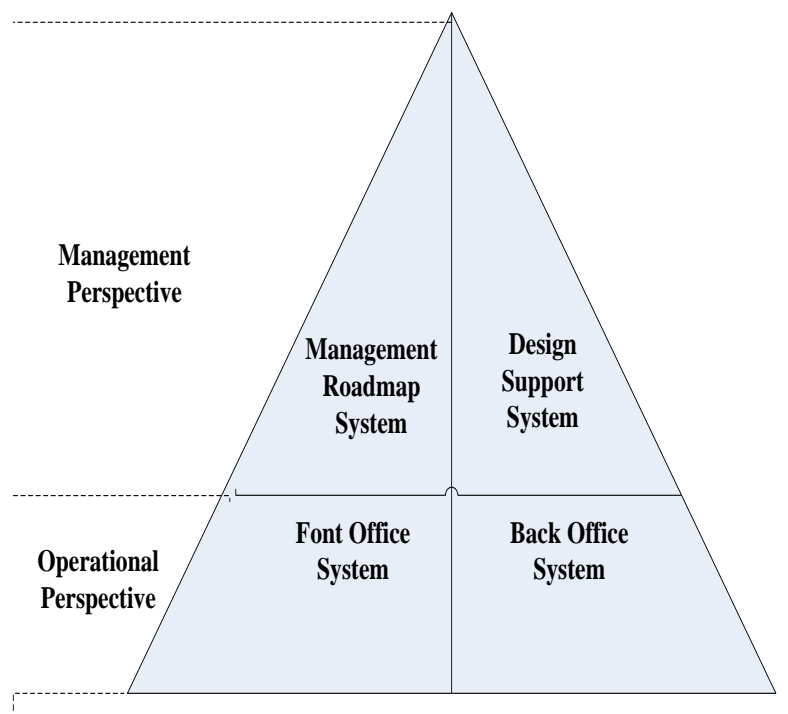

Fig. 7. Organizational Perspective Framework IPDC [9] 
Based on picture 7 (seven), we can see that the portfolio for information system application that needed by IPDC can be grouped into 2 (two) main parts, i.e. Management perspective and Operational perspective.

\section{Management Perspective}

Management perspective can be grouped into sub-parts, i.e. management reporting system and decision support system. Operational perspective can be grouped again into Front Office System and Back Office System that can be further broken-down as seen in figure 8 .

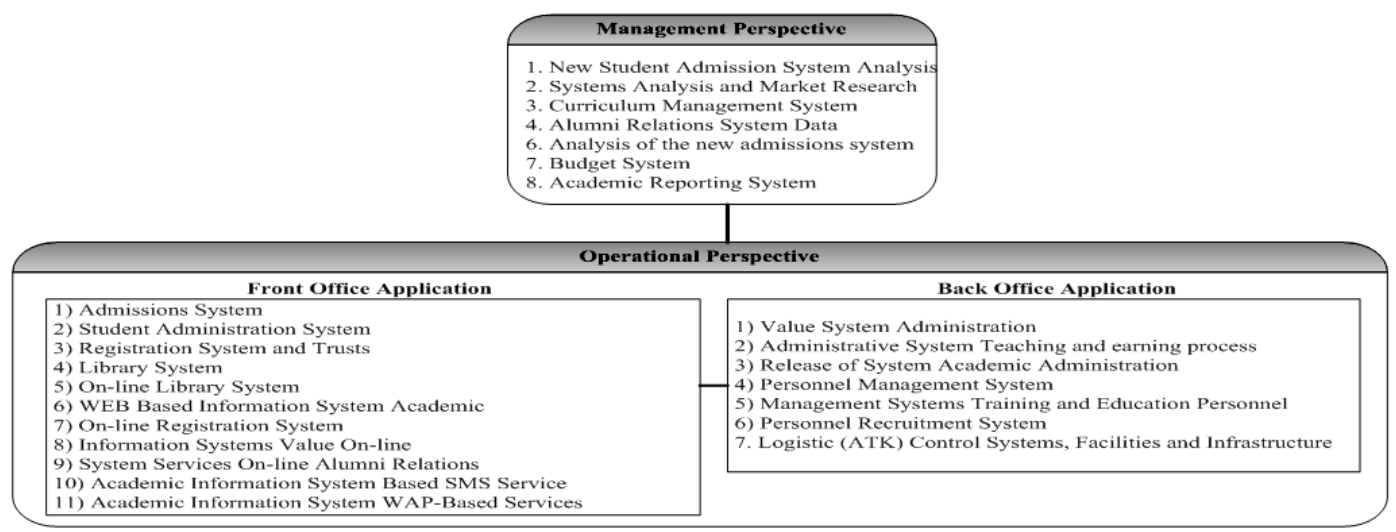

Fig. 8. Perspective Information System Application

\section{Application Portfolio}

Application portfolio is used to identify application's requirements. Application's requirement portfolio of IPDC can be defined as seen on figure 9 .

\begin{tabular}{|c|c|c|c|}
\hline Strategic & Key Operational & High Potensial & Support \\
\hline$\downarrow$ & $\downarrow$ & 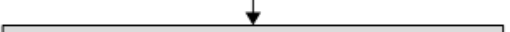 & $\nabla$ \\
\hline $\begin{array}{l}\text { System Analysis Admissions } \\
\text { Systems Analysis and Market } \\
\text { Research } \\
\text { Curriculum Management System } \\
\text { Alumni Relations System Data } \\
\text { Study Progress Analysis System } \\
\text { System Analysis Teaching and } \\
\text { learning process } \\
\text { Budget System } \\
\text { Academic Reporting System }\end{array}$ & $\begin{array}{l}\text { Admissions System } \\
\text { Student Administration System } \\
\text { Registration systems and Trusts } \\
\text { System Administration Grades } \\
\text { System Administration } \\
\text { Teaching and learning } \\
\text { process } \\
\text { Release of Academic } \\
\text { Administration System }\end{array}$ & \begin{tabular}{|l} 
WEB Based Information System Academic \\
On-line Registration System \\
Grade Information System On-line \\
Alumni Relations Service System On-line \\
Academic Information System Based SMS \\
Service \\
Academic Information System WAP-Based \\
Services
\end{tabular} & $\begin{array}{l}\text { Personnel Management System } \\
\text { Management Systems Training And } \\
\text { Education Of Personnel } \\
\text { Personnel Recruitment System } \\
\text { Library System } \\
\text { Office Stationery Control Systems, } \\
\text { Facilities And Infrastructure }\end{array}$ \\
\hline & & $\begin{array}{l}\text { Institute Profile-Based Multimedia Systems } \\
\text { Internal Services System Message }\end{array}$ & \\
\hline
\end{tabular}

Fig 9. Application System Requirements

\subsubsection{Architecture Technology Model}

In this technology architecture, we will describe enterprise network architecture and business system architecture of IPDC based on gathered business system on the preceding steps. Network architecture definition that will be described is a proposed architecture to improve or give additional ability that will support the application system defined on previous chapter. The model is on Figure 10.

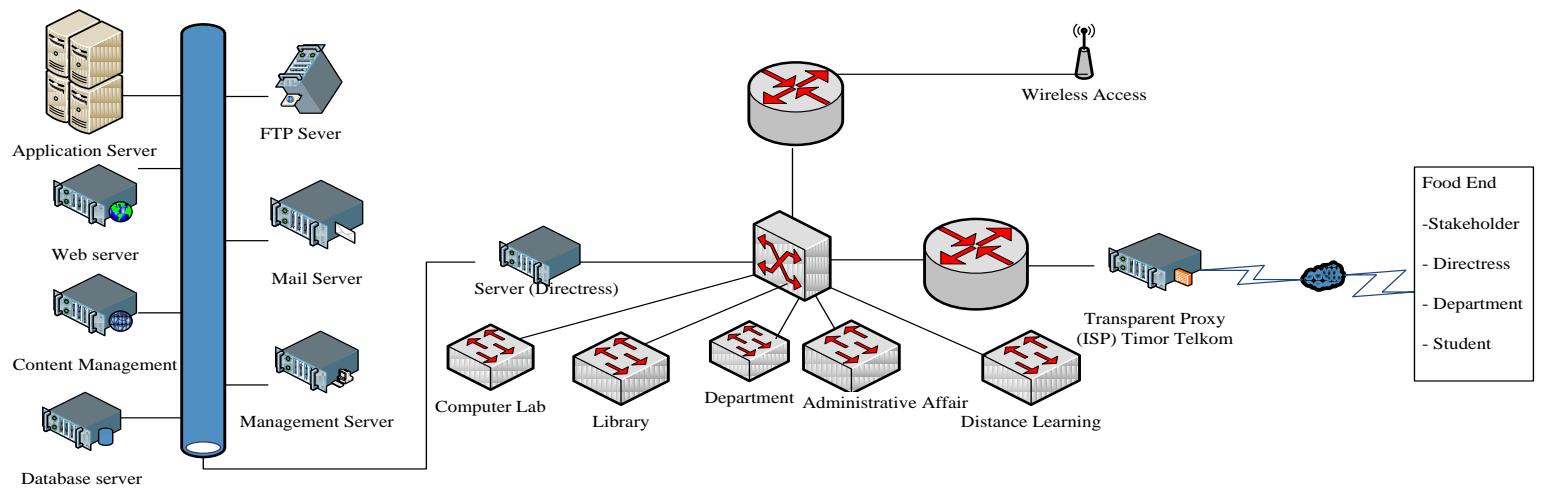

Fig.10. Conceptual Networking Architecture Model 
Based on conceptual networking architecture in Figure 10, we need to propose Business System Architecture in IPDC that can be seen on Figure 11.

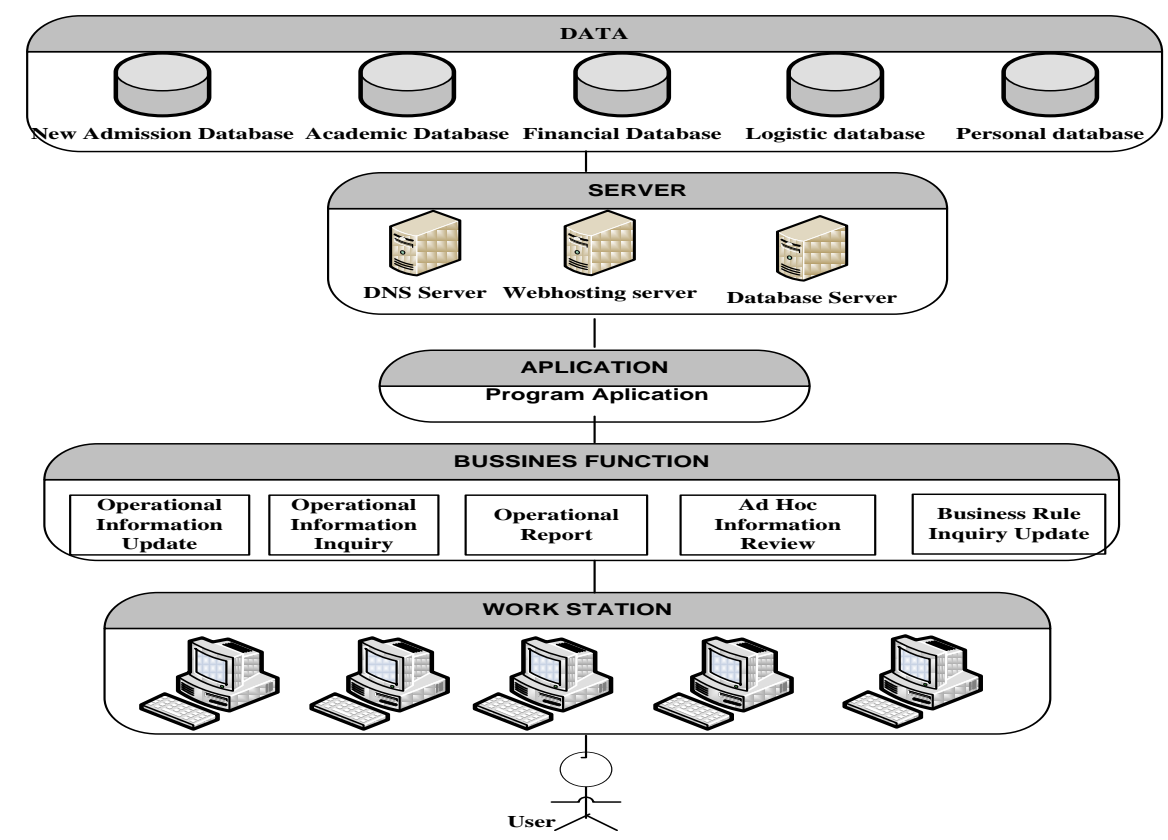

Fig. 11. Proposed Business System Architecture of IPDC

\subsection{Implementation of Academic Information System Planning}

Based on analysis result of EAP concerning about proposed data architecture, data application model and technology architecture model, the information system application that become priority to be implemented in IPDC is web-based Academic Information System that the DFD can be seen on Figure 12.

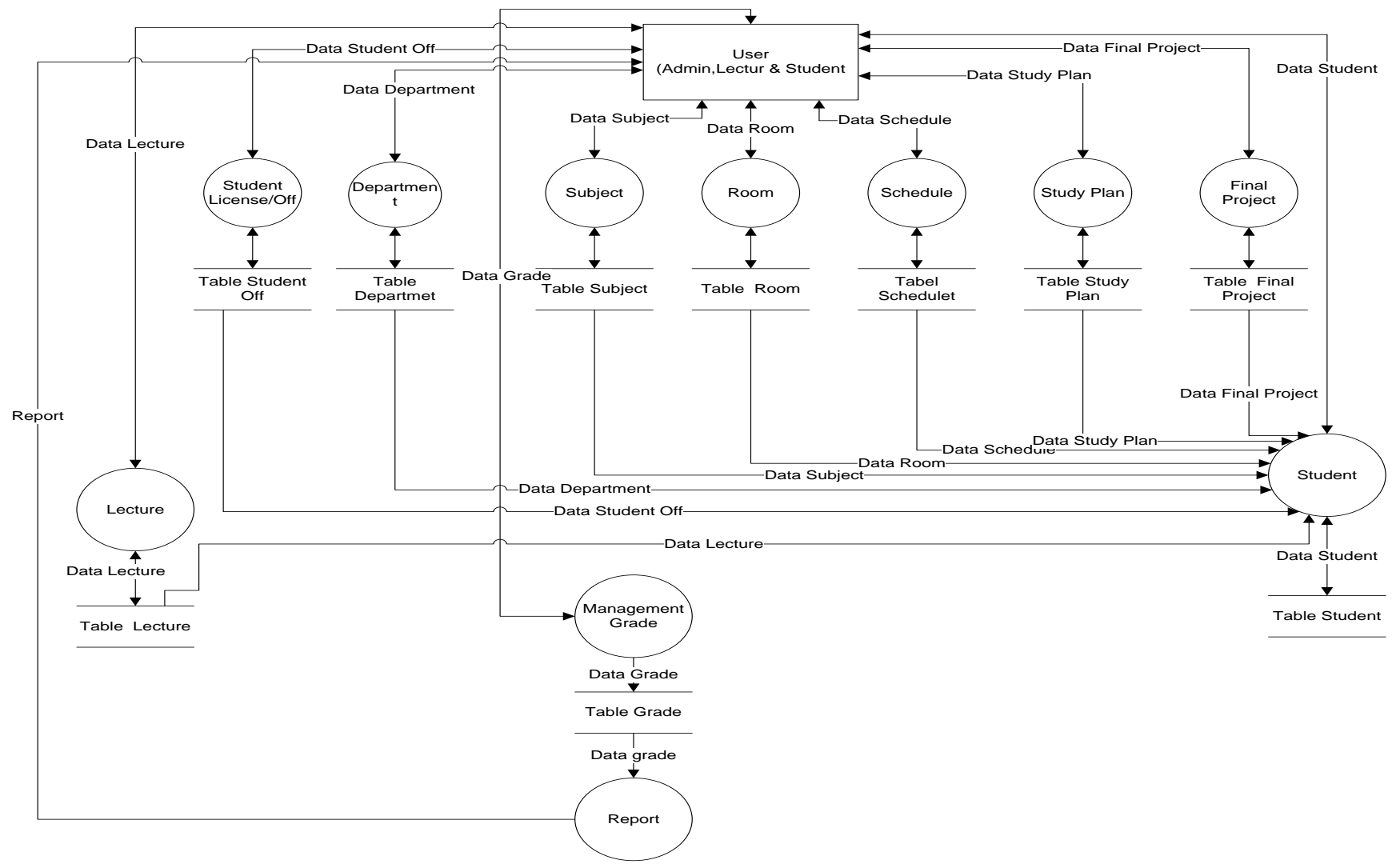

Fig. 12. Data Flow Diagram of IPDC's Academic Information System 


\section{CONCLUSION}

Based on EAP analysis result above, we can conclude that:

- Enterprise Architecture analysis is needed to develop information system in IPDC.

- Analysis of EA, data, application and technology can be utilized by IPDC as a base for developing an information system so the development does not miss from the company goal and does not nullify the integration between business unit on IPDC.

- Application perspective that will be implemented on IPDC would be 26 in total but on this paper we only discuss Academic Information System and IPDC will continue the development of the system as needed.

EAP modeling has described data architecture, application and technology, so, in the next research, required to;

- Implement the suggested application model based on researcher needs.

- Applications chosen have to be exact and support organization business functionality so the benefit will be optimum.

- In the planning of EAP implementation need to include the risk of management component

\section{REFERENCE}

[1] Kurniawan Bobi, Enterprise Architecture Planning Sistem Informasi Pada Perguruan Tinggi Swasta Dengan
Zachman Framework, Majalah Ilmiah Unikom, Vol.9. No1, FTI

[2] Surendro Kridanto. 2007. Pemanfaatan Enterprise Architecture Planning Untuk Perencanaan Strategis Sistem Informasi.

[3] Ross ET All., Corporate Finance, Mc Graw Hill, Inc, 2005

[4] Doucet Et Al, 2008 Efficient Block Sampling Strategies for Sequential Monte Carlo" ... Estimation For Genome Wide Transcript Analysis, Technical Report 2008

[5] Yunis, R. Surendro K.Panjaitan.E.S. 2010, Pengembangan Model EA Untuk Perguruan Tinggi. Jurnal Ilmiah Teknologi Informasi. Vol 8. No1. 9-18

[6] Mochamad Arifin, Pemanfaatan Media Web Site Sebagai Sistem Informasi Akademik Dan Sarana Pembelajaran Mandiri Dalam Pengaruhnya Dengan Prestasi Belajar Mahaiswa, Jurnal Stikom Vol.6 No. 2 Sept 2005

[7] Edward Gulo Arisman, Pendekatan Deduktif Dan Induktif Dalam Penelitian, 2012

[8] Manual Admin IPDC Dili Timor Leste, 2012

[9] Steven Alter Information Systems: Foundation Of EBusiness (4th Edition), 2002 